\title{
The Model of Policy and Regulation of Local Content Requirements in Indonesia
}

\author{
Muh. Risnain* \\ DOI: https://doi.org/10.22304/pjih.v5n3.a10
}

Submitted: June 24, 2018 | Accepted: January 10, 2018

\begin{abstract}
Nowadays, many states apply policy on the Local Content Requirements (LCRs) as an instrument of international trade. The international trade law under the framework of World Trade Organization (WTO) actually requires equal treatment for both foreign and local business actors. However, the policy to apply LCRs based on national interest ignores the WTO's principles. Since 2009, Indonesia is one of the states that apply LCRs based on national economic requirement and an argumentation that, currently, Indonesia has not become a party of GPA (Government Procurement Agreement). Therefore, Indonesia has no obligation to apply equal treatment principle in the procurement of government's goods and service. The Indonesian government needs to construct LCRs regulation that can fulfill both international trade interests and national economic interests. Article 22 (3) of the Law Number 7 of 2014 on Trade mandates a Regulation of the Minister of Trade to set out the application of LCRs. Therefore, the Draft of the Regulation of the Minister of Trade on the use of domestic products is the most important legal requirement for current Indonesian trade. Therefore, this study suggests that the Minister of Home Affairs immediately should process the Regulation of the Minister of Trade as a Law on the use of domestic products. The results of the process can be a reference for government's, as well as local governments', agencies on the application of LCRs.
\end{abstract}

Keywords: international trade law, national Interest, regulation.

\section{Model Pengaturan Kewajiban Penggunaan Kandungan Lokal di Indonesia}

\begin{abstract}
Abstrak
Kebijakan negara-negara untuk memberlakukan LCRs dalam perdagangan internasional dewasa ini merupakan sebuah kenyataan yang dihadapi. Hukum perdagangan internasional dalam kerangka WTO sesungguhnya bertentangan dengan prinsip-prinsip utama WTO terutama prinsip national treatment yang menghendaki perlakuan yang sama antara pelaku usaha asing dan pelaku usaha dalam negeri. Namun demikian kebijakan yang memberlakukan LCRs berdasarkan pada prinsip kepentingan ekonomi nasional dapat saja mengabaikan prinsip-prinsip WTO. Indonesia sebagai salah satu negara yang menerapkan kebijakan LCRs sejak 2009 mendasarkan kebijakan pada kepentingan ekonomi nasional juga didasarkan pada argument bahwa hingga saat ini Indonesia belum menjadi pihak dalam GPA. Sehingga Indonesia dapa bebas dari kewajiban untuk menerapkan prinsip equal treatment dalam pengadaan barang dan jasa pemerintah. Model regulasi kebijakan LCRs di Indonesia yang dapat mengharmoniskan kepentingan perdagangan internasional dan
\end{abstract}

PADJADJARAN Journal of Law Volume 5 Number 3 Year 2018 [ISSN 2460-1543] [e-ISSN 2442-9325]

* Lecturer of the Faculty of Law, Universitas Mataram (Mataram University), West Nusa Tenggara, Jl. Majapahit No. 62 Mataram, NTB., risnain82@gmail.com, S.H. (Universitas Mataram), M.H., Dr. (Universitas Padjadjaran). 
kepentingan ekonomi nasional Indonesia adalah dengan segera mengatur peraturan khusus tentang LCRS. Pasal 22 (3) undang-undang Nomor 7 tahun 2014 tentang perdagangan mengamanatkan agar pemberlakuan LCRs diatur melalui Peraturan Menteri Perdagangan. Oleh karena itu, Rancangan Peraturan Menteri Perdagangan tentang penggunaan produk dalam negeri merupakan kebutuhan hukum terpenting yang saat ini dibutuhkan oleh dunia perdagangan Indonesia. Oleh karena itu, kajian ini menyarankan agar Menteri Dalam Negeri segera memproses Peraturan Menteri Perdagangan sebagai Undang-undang tentang penggunaan produk dalam negeri. Hasil dari proses tersebut dapat menjadi rujukan bagi lembaga pemerintah, maupun pemerintah daerah, tentang LCRs.

Kata kunci: hukum perdagangan internasional, kepentingan nasional, regulasi.

\section{A. Introduction}

The problem of Local content requirements (LCRs) is a serious issue of international trade. The international trade law under the framework of World Trade Organization (WTO) does not allow discriminative policies. On the other sides, many states apply LCRs policy to escalate their economy and national industry. Up to now, the LCRs issue is a controversial issue. Conceptually, LCRs are the unilateral policy of a state to utilize local products. It obligates all business actors to use local products. The obligation implies taxation for both local and foreign companies that build in a state. The LCRs policy can be done by government on all levels, either central, provincial, or cities and regencies. Considering that the main principle of international commerce is the discrimination exclusion, the LCRs are actually a violation on the General Agreement on Tariff and Trade (GATT). However, developed and developing states still practice the LCRs. Many parties assume that the LCRs are the new type of protection in which the obligation of "local contents" is the foundation. It is different with classic-type of protection, tariff and non-tariff. The LCRs are assumed as the one of the localization barriers to trade. ${ }^{1}$

The debate over the LCRs in international trade leads to two views. The first view accepts the existence of LCRs and the second rejects the LCRs. The supporters of LCRs argue that LCRs encourages national economic growth such as providing employment and empowering domestic industries. In general, developing countries argue that the LCRs are intended to protect infant industries and the environment. The detractors of LCRs assume that LCRs have an impact on the inefficiency of resource allocation, adverse effects on trade, inflation at the retailer and worker level. They also question the direct benefits to the environment. ${ }^{2}$ According to a study by Peterson Institute for International Economics, the Policies of LCRs give impacts on high economic costs and provide uncertainties on protection.

Indonesia is a state party of WTO agreement that faces the problem of LCRs. Therefore, Indonesia has a legal obligation to fulfill all WTO law principles, including the non-discrimination principle. On the other hand, Indonesia has national

\footnotetext{
See Holger P. Hestermeyer and Laura Nielsen, "The Legality of Local Content Measures under WTO Law", Journal of World Trade, Vol. 48, No. 3, 2014.

2 Jan Cristoph Kuntze and Tom Morenhout, Local Content Requirements and the Renewable Energy Industry - $A$ Good Match?, Geneva: ICTSD, 2013, pp. 4-7.
} 
economic interests to protect. Since the LCRs issue is still controversial in international trade law, the arrangement still becomes a source of debates. The regime of arrangement becomes an anomaly because the practice is contradicted to the non-discrimination principle, mainly the national treatment, which requires equal treatment towards all business actors, either local or foreign actors. However, almost all states practice the LCRs. According to the press release delivered by the Committee on Trade-Related Investment Measure (TRIMS) of the WTO, fourteen states complain on states' investment policy in Indonesia, Russia, China, and others because these states apply the LCRs policies. According to other WTO members, the LCRs policies contradict to national treatment principle.

In the context of international trade law, the review on the LCRs should refer to the main legal sources of international trade: the international agreements under the WTO. The legal framework covered by the WTO agreements does not regulate the LCRs issues specifically. They are spread in other agreements such as Article 3 of GATT (the non-discrimination principle), investment agreement (Trade Related Investments Measures), agreements on subsidy and countervailing duties, and agreements on government procurement.

On the other hand, various Indonesian LCRs policies are protested by other states, which lead to dispute settlement in DSB WTO. In such contexts, conceptual issues will emerge in different poles, the concept of trade liberalization based on WTO legal principles and LCRs imposition that prioritizes interests of industrial and national trade. Up to now, many Indonesian trade policies have been protested by other states but Indonesia's national interests are an important matter that must be considered to build the independence of the national economy. Various Indonesian laws and regulations have regulated the LCRs policies.

This study aims to harmonize the two contradictory concepts above so that a model of regulation can be found to be a solution in resolving Indonesian legal problems. In the first description, the LCR is described from the perspective of international trade law. Subsequently, it is followed by the elaboration of Indonesian LCRs policies. A description of Indonesian policies that violates WTO's international trade law lies on in the following description before the model of Indonesian LCRS policy regulation is proposed.

\section{B. The International Trade Law Perspectives on Local Content Requirements}

The existence of international trade law in various international agreements aims to liberate the international trade. Technically, the international agreements are efforts to remove the obstacles of international trade, either tariff or non-tariff. The international societies, represented by states, establish various international organizations such as WTO, AFTA, ACFTA, etc. ${ }^{3}$

Currently, almost all states of the world have followed the international trade system under the international trade law regime. States of the world have established various international agreements to be an international law that

3 Joseph E. Stiglitz, Making Globalization Work, New York: W.W. Norton and Company Inc., 2006, p. 37. 
regulates international trade. On the other hand, anti-free trade groups view that free trade minimizes the role of states so that it is a form of "new colonialism" of the developed countries on the developing countries. ${ }^{4}$

Free trade, which removes the trade barriers, opens the opportunity for countries to get profits from international trade activities. According to WTO, the international trade has brought welfare for countries and the increase of export and import of goods and service, opened job vacancies, added exchanges, and been resources of country development.

International trade agreements frame the formation of international trade organizations and become a law for states-parties that are applied in law globalization. ${ }^{5}$ The phenomena of law globalization have implications on international law, ${ }^{6}$ in which states agree to form law norms to arrange their relationship in international trade law. ${ }^{7}$ The existence of international trade law brings implications to states-parties. The first, the international trade agreements binds as law for all states. Based on Pacta Sunt Servanda principle, all states must obey all international agreements where they involve as parties. The second, the states-parties have law obligations to adapt their national laws to the international trade agreement standards. ${ }^{8}$

In the midst of globalization and international trade law, national law positions in a whole system of law. States of the world realize the existence of international trade law binding them. There are no isolated states since it would be difficult to isolate from globalization and law liberalization. Almost all states of the world are now parts of globalization. ${ }^{9}$ Nevertheless, states of the world still have authority to protect their respective markets domestically and their national interests through law instruments.

According to Van De Bosce, ${ }^{10}$ international trade law is needed for several reasons. First, it limits governments' policy that tends to protect domestic market and refuse foreign actors. Second, it provides certainty for business actors and investors on security and predictability of international trade. Third, it protects national interests that potentially are influenced. Fourth, it provides equal chances for all states to get profits through international trade.

\footnotetext{
Adolf Warouw, "Multilateral Trade System in WTO Frame, An Observation Toward Rule-Based System", International Law Journal, Vol. 1, No. 2, 2004, p. 233.

5 Ridwan Khairandi, "Politik Hukum Indonesia dalam Menghadapi Globalisasi Ekonomi dan Hukum" in Ni'matul Huda and Sri Hastuti Puspitasari (ed.), the Contribution of Ideas for the $50^{\text {th }}$ Anniversary of Prof. Dr. Moh. Mahfud M.D., S.H.: Retrospeksi terhadap Masalah Hukum dan Kenegaraan, Yogyakarta: FH UII Press, 2007, pp. 61-62.

6 Satjipto Rahardjo, "Pembangunan Hukum Di Indonesia Dalam Konteks Situasi Global”, in Khudzaufah Dimyati and Kelik Wardono (eds.), Problema Globalisasi: Perspektif Sosiologi Hukum, Ekonomi dan Agama, Surakarta: Muhammadiyah University Press, 2000, pp. 13-14.

7 Huala Adolf, Hukum Perdagangan Internasional, Jakarta: Rajawali Press, 2005, p. 12.

8 Sumaryo Suryokusumo, Studi Kasus Hukum Internasional, Jakarta: Tatanusa, 2007, p. 43.

9 Jimly Assidiqqie, Konstitusi Ekonomi, Jakarta: Kompas Gramedia, 2010, pp. 68-70.

10 Peter Van De Bosche, The Law and Policy of the World Trade Organization, Text, Cases, and Materials, Cambridge: Cambridge University Press, 2006, p. 25.
} 
International trade liberation is arranged in various international agreements. It is based principles of fairness. ${ }^{11}$ Djiwadono ${ }^{12}$ says that international trade system must be able to create free, fair, and opened market for all business actors. In practice, international trade encounters unfair trade practice that inflicts losses other states. ${ }^{13}$

International agreement is the central of main law that arranges international relationship and binds as a valid law. States parties must obey it. The law binds states on two obligations. First, states parties ought to obey international agreements. Second, states parties ought to apply international agreements in their national laws. Wiradipradja ${ }^{14}$ mentions that the involvement of Indonesia in WTO generates two implications. First, Indonesia is bound by the regulations in agreements of WTO along with appendices. Second, the national law needs completion of legislation to suit the national law to the international agreements. Therefore, states parties ought to produce legal policies to accommodate the interests of trade liberalization and national interests. Indonesia, as a developing country that moves toward industrialized countries, ought to make legal development policies before the emergence of other international trade liberalization agreements.

The LCRs issue, currently is a serious issue in international trade. There are two paradoxical facts in this issue. The first fact is that international trade law does not allow discriminative policies but the second fact show that most states apply LCRs policy to move their economy and national industry. Indonesia also faces the equal problem. Indonesia is a state party of WTO through the Law Number 7 of 1994 on the Formation of WTO. Therefore, Indonesia ought to follow all rights and obligations of WTO. On the other hand, Indonesia has national interests in trade and industrial sectors. The Law Number 7 of 2014 on Trade sets out national interests in international trade. The law requires the government to pay attention on national interests in trade, including the application of LCRs.

International trade law is understood as a collection of norms, principles, and process that constitute various international agreements or international conventions in trade sectors. In addition, international trade law must be understood as international agreements, which is formalized in international covenants that can be multilateral, plurilateral, or bilateral. In this context, international trade law is a branch of international law. The international trade law arranges national policies in trade. Therefore, trade law intersects to other branches of national laws, like constitutional, administration, criminal, etc.

11 Koffi Anan, "Laying the Foundations of a Fair and Free World Trade System" in Gary P. Sampson (ed.), The Role of the World Trade Organization in Global Governance, New York: United Nations University Press, 2001, p. 20.

12 J. Sudrajad Djiwandono, Perdagangan dan Pembangunan: Tantangan, Peluang dan Kebijaksanaan Perdagangan Luar Negeri Indonesia, Jakarta: LP3ES, 1992, p. 138.

13 John $\mathrm{H}$ Jackson (ed.), Antidumping Law and Practice: A Comparative Study, Michigan: University of Michigan Press, 1989, p.8.

14 E. Saefullah Wiradiprdja, "Konsekuensi Yuridis Keanggotaan Indonesia Dalam Wto-Gats Dan Pengaruhnya Terhadap Industri Dan Perdagangan Jasa", Jurnal Hukum Internasional UNPAD Vol.I/I 2002, Vol. 1, No. 1, 2002, p. 2. 
Conceptually, LCRs are the unilateral policy of a state to utilize local products. It obligates all business actors to use local products. The obligation implies taxation for both local and foreign companies that build in a state. The LCRs policy can be done by government on all levels, either central, provincial, or cities and regencies. Considering that the main principle of international commerce is the discrimination exclusion, the LCRs are actually a violation on the General Agreement on Tariff and Trade (GATT). However, developed and developing states still practice the LCRs. Many parties assume that the LCRs are the new type of protection in which the obligation of "local contents" is the foundation. It is different with classic-type of protection: tariff and non-tariff. The LCRs are assumed as the one of the localization barriers to trade. ${ }^{15}$

The debate over the LCRs in international trade leads to two views. The first view accepts the existence of LCRs and the second rejects the LCRs. The supporters of LCRs argue that LCRs encourages national economic growth such as providing employment and empowering domestic industries. In general, developing countries argue that the LCRs are intended to protect infant industries and the environment. The detractors of LCRs assume that LCRs have an impact on the inefficiency of resource allocation, adverse effects on trade, inflation at the retailer, and worker level. They also question the direct benefits to the environment. ${ }^{16}$ According to a study by Peterson Institute for International Economics, the Policies of LCRs give impacts on high economic costs and provide uncertainties on protection.

1. The support conferred by LCRs on domestic producers can be highly variable (in contrast to an explicit tariff or subsidy), and government officials usually have little understanding of the effective rate of protection. For a given measure, protection could easily range from 20 percent to 100 percent ad valorem tariff equivalent.

2. LCRs can insulate domestic firms from foreign competition, causing lags in the adoption of new technology and defeating the goal of nourishing high-tech infant industries.

3. Because LCRs work in an opaque manner, their adverse impact on downstream producers - in terms of price, quality, and delayscan be difficult to calculate, which helps insulate them from both domestic reform and international surveillance.

4. LCRs increase delays and costs, especially in infrastructure projects. These impacts are often unknown but highly variable, because they depend on supply and demand conditions in the local economy.

15 Isabelle Ramdoo, "Local Content, Trade, and Investment: Is There Policy Space Left for Linkages Development in Resource-rich Countries?", Discussion Paper, European Centre for Development Policy Management, No. 205, 2016, p. 18.

16 Jan Cristoph Kuntze and Tom Morenhout, Local Content Requirement and the Renewable Energy Industry - $A$ Good Match?, Geneva: ICTSD, 2013, pp. 4-7. 
5. LCRs are susceptible to corruption and favoritism, especially when the domestic industry has relatively few firms.

6. LCRs are seldom bound by time limits or "sunset" provisions, a feature that leads to long-lasting market distortions ${ }^{17}$.

In the context of international trade law, the review on the LCRs should refer to the main legal sources of international trade: the international agreements under the WTO. The legal framework covered by the WTO agreements does not regulate the LCRs issues specifically. They are spread in other agreements such as Article 3 of GATT (the non-discrimination principle), investment agreement (Trade Related Investments Measures), agreements on subsidy and countervailing duties, and agreements on government procurement. Furthermore, the paper explains some WTO rules concerning the LCRs practices.

\section{Article III (4) of GATT on the National Treatment Principle}

National treatment principle is a manifestation of non-discrimination principle. ${ }^{18}$ The national treatment principle regulates that the states parties must give the equal treatment towards all, either import or export, products. The national treatment principle is regulated in Article III (4).

The products of the territory of any contracting party imported into the territory of any other contracting party shall be accorded treatment no less favorable than that accorded to like products of national origin in respect of all laws, regulations and requirements affecting their internal sale, offering for sale, purchase, transportation, distribution or use. The provisions of this paragraph shall not prevent the application of differential internal transportation charges, which are based exclusively on the economic operation of the means of transport and not on the nationality of the product.

According to Article III (4), national treatment principle is valid wide in scope ${ }^{19}$ toward all taxes and other levies. This principle is valid towards regulations, arrangements, and qualifications that influence sales, purchases, distributions, or product use in domestic market. This principle also gives protection towards efforts caused by administrative and legislative policies. ${ }^{20}$

Adolf ${ }^{21}$ says that the principles of Most Favored Nation and National Treatment are central principles in the GATT framework. Both principles also become a reference in TRIPS (the Article 3) and GATS. In service trade, the states parties of WTO ought to give equal treatments towards all service providers, either domestic or international. However, this principle provides exceptions in ${ }^{22}$

Cathleen Cimino (et.al), "A Proosed Code to Discipline Local Content Requirement", Policy Brief, Peterson Institute for International Economics, Number PB14 6, 2014, p. 3.

18 Ibid.

19 Oliver Long, Law and Its Limitations in the GATT Multilateral Trade System, Dordrecht: Martinus Nijholf Publisher, 1987, p. 9.

20 Huala Adolf, op.cit., p. 77.

21 Ibid.

22 Ray August (et.al.), International Business Law, $6^{\text {th }}$ edition, London: Pearson, 2013, p. 55. 
(1) the discrimination in goods auction by government agency for government only; ${ }^{23}$

(2) the discrimination in subsidy payment to domestic producer; ${ }^{24}$

(3) the discrimination in screening towards domestic electronic-cinema production; ${ }^{25}$ and

(4) the maintenance of treatment given before the GATT $1947 .{ }^{26}$

Referring to the provisions above, the practice of LCRs is actually a type of discrimination in international trade because the government gives certain preferences to domestic business actors to provide goods with local content. However, Article III provides an escape clause for the principle for the policy of auctioning goods by government agencies, which is intended for the interests of the government.

\section{Article III (5) of GATT}

Article III (5) of GATT prohibits states parties of GATT, or WTO, to make national legal policies that regulate the obligation to use products with a certain proportion of domestic products since it contradicts the national treatment principle.

No contracting party shall establish or maintain any internal quantitative regulation relating to the mixture, processing, or use of products in specified amounts or proportions, which requires, directly or indirectly, that any specified amount or proportion of any product which is the subject of the regulation must be supplied from domestic sources. Moreover, no contracting party shall otherwise apply internal quantitative regulations in a manner contrary to the principles set forth in paragraph 1.

\section{Article III (8) of GATT}

The article further arranges the exceptions in Article III (4). This provision essentially states that the national treatment principle cannot be applied to laws, regulations, or requirements that regulate the procurement of goods and services by government institutions, which are intended for the interests of the government, not for commercial purposes. The provisions in this article also stipulate that the national treatment principle should not prevent the government from providing subsidies that are exclusive to domestic producers including payments to local producers, taxes, or payment obligations carried out in accordance with this article and provisions on the impact of subsidies through government payments towards payment of domestic products.

a) The provisions of this Article shall not apply to laws, regulations or requirements governing the procurement by governmental agencies of products purchased for governmental purposes and not with a

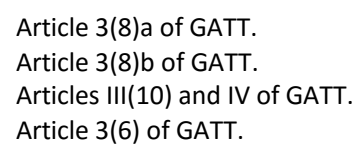


view to commercial resale or with a view to use in the production of goods for commercial sale.

b) The provisions of this Article shall not prevent the payment of subsidies exclusively to domestic producers, including payments to domestic producers derived from the proceeds of internal taxes or charges applied consistently with the provisions of this Article and subsidies effected through governmental purchases of domestic products.

\section{a. Article $\mathbf{1 . 1}$ of the Agreement on Subsidies and Countervailing Measures}

Another provision that has a correlation with LCRs policy is the Article 1.1 of the Agreement on Subsidies and Countervailing Measures. In the article, subsidy is defined as the following.

"...there is a financial contribution by a government or any public body within the territory of a Member (referred to in this Agreement as "government"), i.e. where:

a) a government practice involves a direct transfer of funds (e.g. grants, loans, and equity infusion), potential direct transfers of funds or liabilities (e.g. loan guarantees);

b) government revenue that is otherwise due is foregone or not collected (e.g. fiscal incentives such as tax credits);

c) a government provides goods or services other than general infrastructure, or purchases goods;

d) a government makes payments to a funding mechanism, or entrusts or directs a private body to carry out one or more of the type of functions illustrated in (i) to (iii) above which would normally be vested in the government and the practice, in no real sense, differs from practices normally followed by governments;

The Article 3.1(b) further regulates subsidies that are prohibited. It covers subsidies in an emergency, both in completely and in part, of the use of domestic products rather than the use of imported products.

"Except as provided in the Agreement on Agriculture, the following subsidies, within the meaning of Article 1, shall be prohibited:...(b) subsidies contingent, whether solely or as one of several other conditions, upon the use of domestic over imported goods."

\section{b. Articles 2.1 and 2.2 of Trade Related Investment Measures (TRIMs)}

Another provision that has a correlation with LCRs is the Agreement on Investment. Articles 2.1 and 2.2 of TRIMs stipulates that without violating the rights and the obligations of states parties in the implementation of TRIMs, they ought to carry out the provisions of Article III or Article XI of GATT 1994.

1) Without prejudice to other rights and obligations under GATT 1994, no Member shall apply any TRIM that is inconsistent with the provisions of Article III or Article XI of GATT 1994. 
2) An illustrative list of TRIMs that are inconsistent with the obligation of national treatment provided for in paragraph 4 of Article III of GATT 1994 and the obligation of general elimination of quantitative restrictions provided for in paragraph 1 of Article XI of GATT 1994 is contained in the Annex to this Agreement.

\section{c. Article III.3(b) of the Government Procurement Agreement (GPA)}

Government procurement agreement is a pluraliteral agreement. This agreement does not bind all states parties of WTO but only the signatory states. So far, this agreement only has forty signatory states and most of them are developed states that have powerful economy. The agreement is intended to liberate the procurement of goods and services for governments. This agreement regulates that the procurement of goods and services is opened for all signatory states of GPA.

Article III 3(b) of the GPA reads as follows.

"With respect to all laws, regulations, procedures and practices regarding government procurement covered by this Agreement, each Party shall ensure that its entities shall not discriminate against locally-established suppliers on the basis of the country of production of the good or service being supplied, provided that the country of production is a Party to the Agreement in accordance with the provisions of Article IV."

It means that governments' policies in the procurement of goods and services must not discriminate the suppliers based on the place of production.

International trade law within the framework of the WTO considers LCRs to be policies that conflict with the principle of non-discrimination, especially the national treatment principle. This principle is a corner stone in international trade law. This principle inspires various forms of international agreements in the WTO. The LCRs policy is actually contrary to Articles III(4), III(5), III(8a), and Annex 4 of the Agreement on Government Procurement, Article 3.1b of the Agreement on Subsidies and Countervailing Measures, and Article 2(1) of the Agreement on TradeRelated Investment Measures. Although the policy is contrary to the WTO, almost all states members carry out this policy. During 2008-2009, when the global crisis occurred, states implemented LCRs policies to spur domestic economic growth. Therefore, the policies related to the LCRs are often charged at the WTO.

\section{The Regulation of Local Content Requirements in Indonesian National Laws and Regulations}

The Indonesian Government's has applied policies related to Local Content Requirements since some time ago. The policies, which began in 2009, were applied out within various legal instruments, from the Presidential Regulations, the Presidential Instructions, the Law Number 3 of 2014 on Industry (Industry Law), and the Law Number 7 of 2014 on Trade (Trade Law). The philosophy of the various laws and regulations is the use of domestic products for the procurement of goods and 
services needed by the government, to drive the national economy, and to open employment opportunities.

The existence of LCRs in Indonesian national law began with the issuance of the Presidential Instruction Number 2 of 2009 on the Use of Domestic Products in the Procurement of Government Goods/Services. The main objective of the Presidential Instruction is to optimize government spending in the procurement of goods/services, while at the same time driving growth and empowering domestic industries through the increasing use of domestic products. The spirit of the use of domestic products in the procurement of government goods/services is then regulated in the Presidential Regulation Number 54 of 2010 on the Procurement of Government Goods/Services, which was later amended by the Presidential Regulation Number 70 of 2012. Article 96 (1) of the President Regulation Number 54 of 2010 on the Government Procurement of Goods/Services requires ministries, institutions, agencies, and other government bodies to

(a) maximize the use of goods/services that are produced domestically, including national design and engineering, in the procurement of goods/services;

(b) maximize the use of national goods/services providers; and

(c) maximize the procurement of work packages for micro and small businesses, including small cooperatives.

Furthermore, Article 97 stipulates that (1) the use of domestic products is carried out in accordance with the quantity of domestic components in each goods/services indicated by the level of domestic components; and (2) the domestic products must be used if there are goods/services providers offering goods/services indicated by at least $40 \%$ content of TKDN (Indonesian Domestic Component Level) value plus BMP (Company Benefit Weight).

As the follow up to Presidential Regulation Number 54 of 2010 on the Procurement of Goods/Services of the Government, the Minister of Industry released the Regulation of the Minister of Industry Number 15 of 2011 on the Guidelines for the Use of Domestic Production in the Procurement of Government Goods/Services and the Regulation of the Minister of Industry Number $16 / \mathrm{M}$ IND/PER/2/2011 on the Provisions and Procedures of TKDN and BMP Calculation. In 2014, the Minister of Industry issued the Regulation of the Minister of Industry Number 02/M-IND/PER/1/2014 on the Guidelines for the Increase of the Use of Domestic Products in the Procurement of Government Goods/Services. The Trade Law then completes the obligation of domestic component use, which is arranged in the three laws and regulation. Article 85 of the Trade Law puts the spirit of TKDN use to improve the use of domestic products.

The policy of using domestic products is strengthened by Article 86 (1) of Trade Law, which requires the use of domestic products at

(a) state institutions, ministries, non-ministerial government's institutions, and regional apparatus work units in the procurement of goods/services if the source of funding comes from the state revenue and expenditure budget, 
regional income and expenditure budget, including loans or grants from domestic or overseas; and

(b) state-owned enterprises, local-owned enterprises, and private business entities in the procurement of goods/services if the source of funding comes from the state revenue and expenditure budget, regional income and expenditure budget, and/or the procurement is carried out through a pattern of cooperation between the Government and private sector and/or the resources controlled by the state.

Article 89 of the Trade Law regulates the use of domestic products so that the government only encourages private business entities and the public to increase the use of domestic products. The use of domestic products is carried out by the government through the policy of providing facilities at least in the form of (1) price preferences and ease of administration in the procurement of goods/services; and (2) domestic component level certification.

To strengthen the obligation for government institutions, this provision is supported by the provision of administrative sanctions for officials who procure goods/services without domestic products subject. The administrative sanctions are in the form of (1) written warning, (2) administrative fines; and/or (3) dismissal from the position of procurement of goods/services.

However, the sanction can be ignored if there is a real condition where domestic products are not yet available, or are not sufficient, to meet the needs of domestic goods and services.

The Trade Law also recognizes the policy of using domestic products. Article 22 (1) of the Trade Law regulates that the Government, Regional Governments, and/or other Government's stakeholders, either individually or jointly, seek to increase the use of domestic products. The policy is carried out for the development, empowerment, and strengthening of domestic trade. Technically, the policy of increasing the use of domestic products is carried out by the Government through promotion, socialization, marketing, and the application of the obligation to use domestic products in accordance with law and regulations.

\section{The Appropriateness of Indonesian LCRs to the Law of WTO}

Indonesia has become a state party in the formation of the WTO, which is acknowledged within the Law Number 7 of 1994. Therefore, it is mandatory for Indonesian law to comply with all contents of the WTO agreements. The issuance of LCRs policies, and ignorance of WTO provisions, may trigger other states to consider the Indonesian government violating WTO provisions. The Indonesian government must avoid protests or lawsuits from other states on the DSB of WTO. Indonesia is not fully a party to all WTO agreements, including the Agreement on Government Procurement. Until now, there are only 42 GPA states parties. Indonesia is only an observer. The status makes the Indonesian government not a subject to the GPA. The Indonesian government cannot be sued to the DSB of WTO for violating the GPA. 
Yet, the Indonesian government is bound by the obligations contained in Articles III(4), III(5), III(8a), and Article 3.1b of the Agreement on Subsidies and Countervailing Measures, and Article 2(1) of the Agreement on Trade-Related Investment Measures. The Indonesian government still has to respect the obligation of equal treatment, the prohibition of giving subsidies, and the discrimination of investment as a form of the government's commitment in the WTO. The LCRs policies are very vulnerable to be sued by governments of other states. For example, the United States, Canada, and Japan protested the Indonesian government's policy plan to implement LCRs on the 4G LTE spectrum of telecommunication companies because it benefits local Indonesian telecommunications companies. Therefore, the Indonesian Government needs to be careful and implements a proper strategy to get out of the trap of international trade law.

It cannot be denied that Indonesia has an interest to mobilize and to empower its domestic industry. Therefore, the Indonesian Government also needs to pay attention to domestic industry interests. In line with the interests, since 2009 until now, the Indonesian Government has issued various legal policies that support the use of domestic products. The Law Number 7 of 2014 on Trade and the Law Number 3 of 2014 on Industry represent the spirit of national interest as one of the principles of its regulation. The principle is moved through the obligations to use domestic products for all government agencies.

\section{E. The problems of Indonesian LCRs policies}

The Indonesian LCRs policies are contained in some law instruments. However, the policies generate some serious problems, which must be handled immediately. According to the study, the problems of LCRs are as follows.

\section{The LCRs Policies are not codified in single law and/or regulation}

As described above, the LCRs arrangements in Indonesia are spread in various laws and regulations. At the law level, the LCRs policies are regulated, among others, in the Law Number 4 of 2009 on Minerals and Coal, the Law Number 30 of 2009 on Electricity, the Law Number 3 of 2009 on Industry, and the Law Number 7 of 2014 on Trade. At the level of government regulations, the LCRs are covered by the President Regulation Number 54 of 2010 on the Procurement of Government Goods/Services, which was preceded by the Presidential Instruction Number 2 of 2009 on the Use of Domestic Products in Government Goods/Services Procurement. At the ministerial regulation level, there are at least ten ministerial regulations that have been issued related to LCRs as follows.

1. The Regulation of the Minister of Industry Number 15/M-IND/PER/2/2011 on the Guidelines for the Use of Domestic Products in Government Goods/Services Procurement

2. The Regulation of the Minister of Industry Number 16/M-IND/PER/2/2011 on the Provisions and Procedures for the Calculation of TKDN and BMP 
3. The Regulation of the Minister of Energy and Mineral Resources Number 15 of 2013 on the Use of Domestic Products in Upstream Oil and Gas Business Activities

4. The Regulation of the Minister of Industry Number 02/M-IND/PER/1/2014 on the Guidelines for the Increase of the Use of Domestic Products in Government Goods/Services Procurement

5. The Regulation of the Minister of Energy and Mineral Resources Number 17 of 2013 on the Purchase of Electric Power by PT PLN (Persero) from Photovoltaic Solar Power Plants

6. The Regulation of the Minister of Energy and Mineral Resources Number 19 of 2013 on the Purchase of Electric Power by PT PLN (Persero) from Municipal Waste Incinerators

7. The Regulation of the Minister of Industry Number 68/M-IND/PER/8/2015 on the Provisions and Procedures to Calculate Domestic Content for Electronic and Telematics Products

8. The Regulation of the Minister of Industry Number 69/M-IND/PER/8/2014 on the Provisions and Procedures to Calculate Domestic Content for Electronic and Telematics Products

9. The Regulation of the Minister of Communication and Information Number 27 of 2015 on Technical Requirements of Telecommunication Equipment and/or Devices Based on Long Term Evolution Technology Standards

10. The Regulation of the Minister of Trade Number 70 of 2013 on the Guidelines for Guiding and Structuring Traditional Markets, Shopping Centers, and Modern Shops

Unfortunately, some of the above laws and regulations seem to run independently without any standards and clear criteria that form the basis of the issuance of the LCRs policies. This condition led to the discrepancies among the ministries. Ideally, the LCRs arrangements are regulated in a single law. However, until now, there are no law that regulates LCRs standards and criteria specifically.

\section{The LCRs Policies are sectoral and not coordinated}

The spread of LCRs regulations in various sectoral laws and regulations causes the uncoordinated policies. The regulations issued by ministries/institutions appear to represent institution's moral interests not the well-coordinated national policies. As a result, the implementation level faces the difficulties of implementation. Therefore, the LCRs policies must be carried out from upstream to harmonize the national LCRs policies completely. When the coordination is carried out properly, various interests, not sectoral interests, will be noticed. This certainly facilitates the implementation of the policies.

\section{The LCRs Policies are vulnerable to be protested by other states and can even lead to disputes in WTO}

The next impact is that the LCRs policies are vulnerable to be protested by other states. It even has the potential to result disputes in the DSB of WTO. Protests of 
other states against Indonesian LCRs policies are a consequence of the nature of the LCRs policies that correlate to international trade law. Although the LCRs policy is popular at the national level, this policy may not necessarily be accepted by other states because this policy is definitely related to the business and trade interests of other states.

As explained, essentially, the LCRs policies are contrary to the national treatment principle of GATT/WTO. However, the LCRs policies are widely practiced by various states. In many cases, the LCRs disputes even are settled within the DSB of WTO. Therefore, Indonesia must be careful in issuing LCRs policies. This study argues that Indonesia requires an adequate LCRs regulation to be used as a main standard. The Ministry of Trade has a strategic and legitimate role to issue an anticipatory policy related to the LCRs policies so that the policies are not legally challenged by other states. The strategic role is in the form of preventive advocacy at the level of domestic policy to anticipate and to avoid legal conflicts on every Indonesian LCRs policy.

\section{F. The Objective of the Arrangement of LCRs Policies}

As stated in previous sections, the LCRs policies to date have not been regulated in one specific legislation. Sectoral policies that are not well coordinated are very vulnerable to be protested by other states. Therefore, Indonesia needs legal policies that can overcome these potential problems. This study argues that the right policy concept in overcoming potential problems related to LCRs is through the regulation of the LCRs policies in Indonesian national law comprehensively. As a start, Article 22 (1) of Trade Law stipulates that the Government, the Regional Governments, and/or other stakeholders, either individually or jointly, seek to increase the use of Domestic Products. The policy is carried out in the development, empowerment, and strengthening of domestic trade. Technically, the government runs an increase in the use of domestic products by means of promotion, socialization, marketing, and the obligation to use domestic products in line with the applicable laws and regulations.

The Article 2 (3) of the Trade Law mandates the increase of the use of domestic products to be arranged in a ministerial regulation (in this case, the Ministry of Trade). Therefore, the Regulation of the Ministry of Trade on the use of domestic products becomes an urgent requirement in Indonesian trade currently. To support this argument, several foundations in the Regulation of the Minister of Trade on the Obligation to Use Domestic Products can be promulgated.

The first is the implementation of Article 22 (3) of the Law Number 7 of 2014 on Trade. The Article 121 of the Trade Law mandates the government to enact the regulation no later than two years after the Law is enacted. Therefore, the promotion of the Regulation of the Minister of Trade on the Obligation to Use Domestic Products to be a law is the consistency of the government's policy to implement the Trade Law before 2016, as the last year to promulgate the regulation. 
The second is the solution for the sectoral nature of the LCRs policies. Currently, the LCRs arrangements in Indonesia are spread in various laws and regulations as follows.

1. The President Regulation Number 54 of 2010 on the Procurement of Government Goods/Services

2. The Presidential Instruction Number 2 of 2009 on the Use of Domestic Products in Government Goods/Services Procurement

3. The Regulation of the Minister of Industry Number 15/M-IND/PER/2/2011 on the Guidelines for the Use of Domestic Products in Government Goods/Services Procurement

4. The Regulation of the Minister of Industry Number 16/M-IND/PER/2/2011 on the Provisions and Procedures for the Calculation of TKDN and BMP

5. The Regulation of the Minister of Energy and Mineral Resources Number 15 of 2013 on the Use of Domestic Products in Upstream Oil and Gas Business Activities

6. The Regulation of the Minister of Industry Number 02/M-IND/PER/1/2014 on the Guidelines for the Increase of the Use of Domestic Products in Government Goods/Services Procurement

7. The Regulation of the Minister of Energy and Mineral Resources Number 17 of 2013 on the Purchase of Electric Power by PT PLN (Persero) from Photovoltaic Solar Power Plants

8. The Regulation of the Minister of Energy and Mineral Resources Number 19 of 2013 on the Purchase of Electric Power by PT PLN (Persero) from Municipal Waste Incinerators

9. The Regulation of the Minister of Industry Number 68/M-IND/PER/8/2015 on the Provisions and Procedures to Calculate Domestic Content for Electronic and Telematics Products

10. The Regulation of the Minister of Industry Number 69/M-IND/PER/8/2014 on the Provisions and Procedures to Calculate Domestic Content for Electronic and Telematics Products

11. The Regulation of the Minister of Communication and Information Number 27 of 2015 on Technical Requirements of Telecommunication Equipment and/or Devices Based on Long Term Evolution Technology Standards

12. The Regulation of the Minister of Trade Number 70 of 2013 on the Guidelines for Guiding and Structuring Traditional Markets, Shopping Centers, and Modern Shops

Unfortunately, some of the above laws and regulations seem to run independently without any standards and clear criteria that form the basis of the issuance of the LCRs policies. Every institution seems to issue LCRs policies based on institutional needs without paying attention to the interests of Indonesian national and international trade.

The third covers the anticipative measures to avoid lawsuits from other states. Protests of other states against Indonesian LCRs policies are a consequence of the nature of the LCRs policies that correlate to international trade law. For example, 
the policy of shelter by the Ministry of Energy and Mineral Resources and the policy of $4 \mathrm{G}$ by the Ministry of Industry have been protested by other states. They can be brought to the WTO Dispute Settlement Body. Therefore, the ministerial regulation is expected to be an anticipatory step and becomes a guideline for ministries/agencies and local governments in the implementation of the LCRs.

\section{G. Conclusion}

The policies of states to implement LCRs in international trade today are a reality. The implementation of LCRs actually contradicts the main principles of the WTO, especially the national treatment principle, which requires equal treatment to foreign and domestic business actors. However, the LCRs policies that are based on the principle of national economic interests can ignore the WTO principles. Indonesia is one of the states that has implemented the LCRs policies since 2009. Indonesia bases the policies on national economic interests and an argument that, to date, Indonesia has not been a party to the GPA. Therefore, Indonesia is free from the obligation to implement equal treatment principle in the procurement of government's goods and services.

The Indonesian government has made various policies through various laws and legislations since 2009. This study argues that these policies must continue to be implemented to drive national economic growth and to provide employment opportunities. Indonesia's political choice not to become a state party in the GPA must be maintained to avoid legal obligations and lawsuits of other states at the Dispute Settlement Body (DSB) of WTO.

\section{References \\ Books}

Huala Adolf, Hukum Perdagangan Internasional, Rajawali Press, Jakarta, 2005.

J. Sudrajad Djiwandono, Perdagangan dan Pembangunan: Tantangan, Peluang dan Kebijaksanaan Perdagangan Luar Negeri Indonesia, LP3ES, Jakarta, 1992.

Jackson, John H. (ed.), Antidumping Law and Practice: A Comparative Study, University of Michigan Press, Michigan, 1989.

Jimly Assidiqqie, Konstitusi Ekonomi, Kompas Gramedia, Jakarta, 2010.

Khudzaufah Dimyati and Kelik Wardono (eds.), Problema Globalisasi: Perspektif Sosiologi Hukum, Ekonomi dan Agama, Muhammadiyah University Press, Surakarta, 2000.

Ni'matul Huda and Sri Hastuti Puspitasari (ed.), the Contribution of Ideas for the $50^{\text {th }}$ Anniversary of Prof. Dr. Moh. Mahfud M.D., S.H.: Retrospeksi terhadap Masalah Hukum dan Kenegaraan, FH UII Press, Yogyakarta, 2007.

Sampson, Gary P. (ed.), The Role of the World Trade Organization in Global Governance, United Nations University Press, New York, 2001.

Stiglitz, Joseph E., Making Globalization Work, W.W. Norton and Company Inc., New York, 2006.

Sumaryo Suryokusumo, Studi Kasus Hukum Internasional, Tatanusa, Jakarta, 2007. 
Van De Bosche, Peter, The Law and Policy of the World Trade Organization, Text, Cases, and Materials, Cambridge University Press, Cambridge, 2006.

\section{Other Documents}

Cimino, Cathleen (et.al), "A Proosed Code to Discipline Local Content Requirement", Policy Brief, Peterson Institute for International Economics, Number PB14 6, 2014.

E. Saefullah Wiradiprdja, "Konsekuensi Yuridis Keanggotaan Indonesia Dalam WtoGats Dan Pengaruhnya Terhadap Industri Dan Perdagangan Jasa", Jurnal Hukum Internasional UNPAD Vol.I/I 2002, Vol. 1, No. 1, 2002.

Hestermeyer, Holger P., and Laura Nielsen, "The Legality of Local Content Measures under WTO Law", Journal of World Trade, Vol. 48, No. 3, 2014.

Isabelle Ramdoo, "Local Content, Trade, and Investment: Is There Policy Space Left for Linkages Development in Resource-rich Countries?", Discussion Paper, European Centre for Development Policy Management, No. 205, 2016.

Kuntze, Jan Cristoph, and Tom Morenhout, Local Content Requirements and the Renewable Energy Industry - A Good Match?, ICTSD, Geneva, 2013.

Warouw, Adolf, "Multilateral Trade System in WTO Frame, An Observation Toward Rule-Based System", International Law Journal, Vol. 1, No. 2, 2004.

\section{Legal Documents}

Law Number 3 of 2014 on Industry [Undang-Undang Nomor 3 Tahun 2014 tentang Perindustrian].

Law Number 7 of 2014 on Trade [Undang-Undang Nomor 7 Tahun 2014 tentang Perdagangan].

President Regulation Number 54 of 2010 on the Government Procurement of Goods/Services [Peraturan Presiden Nomor 54 Tahun 2010 tentang Pengadaan Barang/Jasa Pemerintah].

Presidential Instruction Number 2 of 2009 on the Use of Domestic Products in the Procurement of Government Goods/Services [Instruksi Presiden Nomor 2 Tahun 2009 tentang Penggunaan Produk Dalam Negeri dalam Pengadaan Barang/Jasa Pemerintah].

Regulation of the Minister of Industry Number 15/M-IND/PER/2/2011 on the Guidelines for the Use of Domestic Production in the Procurement of Government Goods/Services [Peraturan Menteri Perindustrian Nomor 15 Tahun 2011 tentang Pedoman Penggunaan Produk Dalam Negeri dalam Pengadaan Barang/Jasa Pemerintah].

Regulation of the Minister of Industry Number 16/M-IND/PER/2/2011 on the Provisions and Procedures of TKDN and BMP Calculation [Peraturan Menteri Perindustrian Nomor 16/M-IND/PER/2/2011 tentang Ketentuan dan Tata Cara Penghitungan Tingkat Komponen Dalam Negeri].

Regulation of the Minister of Industry Number 02/M-IND/PER/1/2014 on the Guidelines for the Increase of the Use of Domestic Products in the Procurement of Government Goods/Services [Peraturan Menteri Perindustrian Nomor 02/M- 
IND/PER/1/2014 tentang Pedoman Peningkatan Penggunaan Produk Dalam Negeri dalam Pengadaan Barang/Jasa Pemerintah].

General Agreement on Tariffs and Trade 1947.

Agreement on Government Procurement of World Trade Organization.

Agreement on Trade-Related Investment Measures of World Trade Organization. 